Jurnal Mandala Pharmacon Indonesia, Vol 4.No.2 Desember 2018

Avaiable online at www.jurnal-pharmaconmw.com/jmpi

$p$-ISSN : 2442-6032

e-ISSN : 2598-9979

\title{
Aktivitas Antidiare Buah Okra (Abelmoschus Esculentus L.) Pada Mencit Yang Diinduksi Oleum Ricini
}

\author{
Selpirahmawati Saranani , Jastria Pusmarani \\ Program Studi Farmasi STIKES Mandala Waluya Kendari
}

\begin{abstract}
ABSTRAK
Diare merupakan masalah kesehatan yang masih tinggi angka kejadiannya di Indonesia. Buah okra (Abelmoschus esculantus L.) merupakan tanaman yang tersebar luas di Sulawesi khususnya Sulawesi Tenggara. Masyarakat Sulawesi Tenggara memanfaatkan buah Okra sebagai sayuran. Buah Okra (Abelmoschus esculantus L.) mengandung senyawa fenolik salah satunya senyawa flavonoid yang memiliki aktivitas antioksidan. Penelitian ini bertujuan untuk memperoleh informasi tentang aktivitas buah Okra yang dapat bekerja sebagai antidiare. Penelitian aktivitas buah okra sebagai antidiare belum pernah dilakukan sehingga perlu dilakukan penelitian untuk mengetahui efek antidiare buah
\end{abstract}

Okra pada mencit yang diinduksi oleum ricini. Untuk melihat diare yang disebabkan karena pemberian oleum ricini, maka diamati frekuensi dan bentuk dari feses mencit selama 3 jam. Data dianalisis dengan menggunakan uji $\mathrm{T}$ dengan nilai $\mathrm{P}=0,000$ sehingga dapat disimpulkan bahwa buah okra memiliki aktivitas sebagai antidiare.

Kata kunci : Buah Okra, Aspirin, Antidiare.

\section{Penulis Korespondensi :}

Jastria Pusmarani

Program Studi Farmasi STIKES Mandala Waluya Kendari

E-mail : triapusmarani20@gmail.com

\section{PENDAHULUAN}

Diare merupakan masalah kesehatan yang masih tinggi angka kejadiannya di Indonesia. Diare hebat sering sekali disertai dengan muntahmuntah, tubuh kehilangan banyak air beserta garam-garamnya, terutama natrium dan kalium. Keadaan ini mengakibatkan tubuh kekurangan kalium (hipokalemia), dehidrasi, dan asidosis, yang dapat berakhir dengan kondisi shock dan kematian (Tjay dan Rahardja, 2007). Di negara berkembang seperti Indonesia, diare menyebabkan kematian sekitar 3 juta penduduk setiap tahun (Anas et al., 2016).

Word Health Organization (WHO) merekomendasikan penggunaan obat tradisional dalam memelihara kesehatan masyarakat, mencegah dan mengibati penyakit, utamanya untuk penyakit kronis, penyakit degeneratif dan kanker. WHO juga mendukung upaya-upaya dalam meningkatkan keamanan dan khasiat dari obat tradisional. Obat tradisional dapat berupa buah dan sayuran yang dikonsumsi setiap hari. 
WHO mendukung studi untuk pengobatan dan pencegahan dari penyakit diare menggunakan praktek pengobatan tradisional. Selain itu, dengan adanya isu back to nature menjadikan penggunaan tanaman obat berkembang sangat pesat dan kembali diminati akhirakhir ini sehingga obat tradisional menjadi salah satu alternatif pengobatan yang sudah diakui dunia, maka obat tradisional perlu dimanfaatkan sebaikbaiknya karena mempunyai makna yang sangat penting.

Buah dan sayur mengandung gizi, serat tinggi, dan antioksidan. Salah satu sayuran yang tinggi akan serat dan kandungan antioksidannya adalah buah Okra (Abelmoschus esculantus L. ). Kandungan zat lainnya yang terdapat pada buah Okra (Abelmoschus esculantus L.) adalah Vitamin C, phytosterol, pectin, dan flavonoid (Axe, 2011).

Flavonoida merupakan salah satu metabolit sekunder. Keberadaannya dalam daun dipengaruhi oleh adanya proses fotosintesis sehingga daun muda belum terlalu banyak mengandung flavonoida (Markham, 1998). Mekanisme senyawa flavonoida sebagai antidiare menghambat gerakan motilitas usus sehingga mengurangi sekresi cairan dan elektrolit serta memperlama waktu transit usus (Anas et al., 2016; Fajrin, 2012; Inayathulla et al., 2010).

Penelitian tentang aktivitas antidiare buah okra belum pernah dilakukan, sehingga dilakukan penelitian untuk mengetahui efek antidiare buah okra (Abelmoschus esculantus L.) pada mencit yang diinduksi Oleum ricini. Penelitian ini sangat penting untuk dilakukan dalam rangka menambah nilai kemanfaatan dari buah okra sehingga dapat menjadi masukan untuk pengembangan obat tradisional yang berkhasiat sebagai obat antidiare.

\section{METODE PENELITIAN}

\section{A. Tempat dan Waktu Penelitian}

Penelitian ini akan dilaksanakan di Laboratorium Farmakologi Farmasi STIKES Mandala Waluya Kendari. Penelitian akan dilaksanakan setelah proposal ini disetujui.

\section{B. Bahan dan Alat Penelitian}

\section{Bahan}

Bahan-bahan yang digunakan dalam penelitian ini buah Okra (Abelmoschus esculentus L.) diperoleh dari daerah Ranometo, konawe selatan.

\section{Hewan Uji}

Berdasarkan rumus Frederer Hewan Uji yang digunakan dalam penelitian ini adalah mencit dengan berat 
badan 20-30 gram dengan umur 6-8 minggu sebanyak 15 ekor.

C. Ekstraksi buah Okra (Abelmoschus esculentus L.)

\section{Pengolahan Sampel}

Buah okra (Abelmoschus esculentus L.) yang sudah diambil, dicuci dengan air mengalir sampai berish lalu dipotong kecil-kecil dan dikeringkan tanpa terkenan sinar matahari langsung. Buah okra diekstraksi dengan etanol $70 \%$. Sebanyak 500 g simplisia Buah okra (Abelmoschus esculentus L.) lalu dimasukkan ke dalam wadah maserasi, kemudian ditambahkan etanol 70. Wadah maserasi ditutup dan disimpan selama 24 jam di tempat yang tidak terkena sinar matahari langsung dengan sesekali diaduk. Selanjutnya disaring dan dipisahkan antara ampas dan filtratnya. Ampasnya dimaserasi kembali dengan etanol $70 \%$ yang baru dengan jumlah yang sama. Hal ini dilakukan selama $3 \times 24$ jam. Ekstrak yang didapat, dikumpulkan dan diuapkan cairan penyarinya sampai diperoleh ekstrak etanol kental. Penguapan ekstrak, dilakukan pada panci Stainless Steel diatas penangas air hingga didapat ekstrak yang kental untuk ditimbang.

\section{Pengujian Aktivitas Antidiare}

Pengujian efek antidiare dari suspensi ekstrak etanol buah okra meliputi uji aktivitas antimotilitas ekstrak etanol buah okra dengan metode transit intestinal, dimana penentuan dosis diawali dengan melakukan orientasi dosis. Dosis orientasi yang digunakan yaitu dosis 50, 75, dan 100 mg/kg bb. Konsentrasi larutan dibuat bervariasi agar pemberian dosis ekstrak etanol buah okra terhadap tikus pada masing-masing kelompok seragam yaitu sebesar 0,8 $\mathrm{ml} / 200 \mathrm{~g}$ bb tikus. Sebanyak 15 ekor tikus jantan dipuasakan selama 18 jam dan dibagi dalam 5 kelompok perlakuan (Azizi, 2012).

Kelompok I yaitu kelompok normal tidak mengalami diare diberi $\mathrm{Na}$ CMC 0,5\%, kelompok II yaitu kelompok kondisi diare (kontrol negatif) diberi oleum ricini sebanyak 2 ml. Kelompok III, IV, dan $\mathrm{V}$ yaitu kelompok uji diberi suspensi ekstrak etanol buah okra dosis 20, 30, dan 40 mg/kg bb. Kelompok VI yaitu kelompok pembanding diberi suspensi loperamid dosis $1 \mathrm{mg} / \mathrm{kg}$ bb. Ekstrak etanol buah okra dan loperamid.

\section{Analisis Data}

Data Pengamatan dianalisis secara statistik dengan menggunakan uji statistik 
Kruskal Wallis $(a=0,05)$ untuk melihat adanya perbedaan kelompok populasi yang dilanjutkan uji Mann-Whitney dengan nilai $a=0,05$ untuk mengetahui letak adanya perbedaan dalam populasi.

\section{HASIL DAN PEMBAHASAN}

Dalam penelitian ini, terlebih dahulu tikus dipuasakan selama 18 jam dengan tetap diberi minum, dengan tujuan untuk mengosongkan usus sehingga mempermudah proses absorpsi pada saluran cerna dan mempermudah pengukuran lintasan marker tinta cina pada usus tikus (Fitriyani et al., 2011). Tikus yang digunakan dalam penelitian ini memiliki berat badan 150-200 g (Inayathulla et al., 2010).

Tinta cina digunakan sebagai marker dalam pengukuran metode transit intestinal. Oleum ricini atau minyak jarak mengandung komponen aktif asam risinoleat yang dapat menginduksi perubahan permeabilitas pada cairan mukosa dan transport elektrolit yang menghasilkan respons hipersekretori dan diare. Asam risinoleat dapat meningkatkan sekresi air dan elektrolit ke dalam usus halus. Pembebasan asam risinoleat dari minyak jarak menyebabkan iritasi dan pembengkakan mukosa usus, yang menyebabkan pelepasan prostaglandin, sehingga dapat meningkatkan sekresi dan motilitas intestinal (Inayathulla et al., 2010).

Loperamid digunakan sebagai pembanding karena dapat menyembuhkan sel yang hipersekresi ke keadaan resorpsi normal, dan dapat mempercepat waktu transit usus halus dan absorbsi air, natrium dan klorida dalam tubuh bila terjadi gangguan elektrolit (Purwaningdyah et al., 2015). Loperamid juga mempunyai efek samping konstipasi dengan memperlambat motilitas saluran cerna dan laju aliran pada usus hingga menuju kolon serta menormalkan keseimbangan absorbsi dan sekresi cairan pada membran mukosa usus dan merupakan agen antidiare yang paling banyak digunakan dan efektif terhadap minyak jarak karena bersifat sebagai antimotilitas dan antisekretorik ((Anas et al., 2016; Misra et al., 2014).

Penelitian memakai metode proteksi terhadap diare oleh Oleum ricini. Oleum ricini (castor oil) atau minyak jarak. Di usus halus, minyak jarak dihidrolisis oleh enzim lipase menjadi gliserol dan asam risinoleat. Asam risinoleat merupakan bahan aktif sebagai pencahar. Obat antidiare diberikan menggunakan 
rute pemberian secara peroral (p.o) yang diinjeksi kerongga mulut hingga tenggorokan dengan injeksi khusus injeksi peroral.

Bahan uji pada penelitian ini menggunakan ekstrak etanol buah okra.
Kerja antidiare ekstrak etanol buah okra pada mencit dengan menginduksikan oleum ricini. Dosis ekstrak etanol daun bidara yang digunakan sebesar 20 $\mathrm{mg} / \mathrm{kgBB}, 40 \mathrm{mg} / \mathrm{kgBB}$ dan $60 \mathrm{mg} / \mathrm{kgBB}$.

Tabel 1. Hasil konsistensi feses antar kelompok perlakuan

\begin{tabular}{|c|c|c|c|c|c|}
\hline \multirow{2}{*}{ No } & \multirow{2}{*}{$\begin{array}{l}\text { Kelompok } \\
\text { Perlakuan }\end{array}$} & \multirow{2}{*}{ Waktu } & \multicolumn{3}{|c|}{ Hewan } \\
\hline & & & 1 & 2 & 3 \\
\hline \multirow{6}{*}{1.} & \multirow{6}{*}{ Normal } & 30 & - & - & Lembek \\
\hline & & 60 & Normal & Normal & - \\
\hline & & 90 & Normal & Normal & - \\
\hline & & 120 & - & Normal & - \\
\hline & & 150 & - & Normal & - \\
\hline & & 180 & - & - & - \\
\hline \multirow{6}{*}{2} & \multirow{6}{*}{$\begin{array}{c}\text { Kelompok kontrol } \\
\text { Negatif } \\
\text { (Oleum Ricini) }\end{array}$} & 30 & Normal & Normal & Normal \\
\hline & & 60 & Lembek & Berlendir & Berlendir \\
\hline & & 90 & Berlendir & - & - \\
\hline & & 120 & Berlendir & - & - \\
\hline & & 150 & - & - & - \\
\hline & & 180 & - & - & - \\
\hline \multirow{6}{*}{3} & \multirow{6}{*}{$\begin{array}{c}\text { Kelompok ekstrak } \\
\text { buah okra } 20 \\
\text { mg/kgBB }\end{array}$} & 30 & Normal & Normal & Normal \\
\hline & & 60 & Berlendir & Berlendir & Berlendir \\
\hline & & 90 & Berlendir & Berlendir & - \\
\hline & & 120 & - & Berlendir & - \\
\hline & & 150 & - & Berlendir & Berlendir \\
\hline & & 180 & - & - & Berlendir \\
\hline \multirow{6}{*}{4} & \multirow{6}{*}{$\begin{array}{c}\text { Kelompok ekstrak } \\
\text { buah okra } 40 \\
\mathrm{mg} / \mathrm{kgBB}\end{array}$} & 30 & - & Normal & \\
\hline & & 60 & Berlendir & Normal & - \\
\hline & & 90 & - & - & Normal \\
\hline & & 120 & - & - & Normal \\
\hline & & 150 & - & - & Normal \\
\hline & & 180 & - & - & - \\
\hline \multirow{6}{*}{5} & \multirow{6}{*}{$\begin{array}{c}\text { Kelompok ekstrak } \\
\text { buah okra } 60 \\
\text { mg/kgBB }\end{array}$} & 30 & - & - & - \\
\hline & & 60 & - & Normal & - \\
\hline & & 90 & - & - & Normal \\
\hline & & 120 & - & Normal & - \\
\hline & & 150 & - & - & - \\
\hline & & 180 & - & - & - \\
\hline
\end{tabular}

Konsisitensi feses ditentukan kelompok yaitu konsistensi berlendir atau dengan cara melihat bentuk feses yang terjadi, dan dikategorikan kedalam tiga berair (BL), konsistensi lembek (L), dan konsistensi normal $(\mathrm{N})$. Dari hasil 
penentuan konsistensi feses, diperoleh data dari masing -masing kelompok perlakuan dipaparkan pada tabel 1 .

Hasil pengamatan pada metode ini yaitu konsistensi feses dan frekuensi diare. Frekuensi diare dan konsistensi feses dihitung berdasarkan keseringan defekasi yang berupa berlendir, lembek dan normal. Hasil percobaan diketahui data rata-rata frekuensi diare sebagai berikut. Rata rata frekuensi diare setelah pemberian oleum ricini dan perlakuan selama 3 jam tertinggi pada kelompok kontrol aquadest. Hal ini terjadi karana kelompok kontrol aquadest tidak diberi perlakuan dengan sedian antidiare.

Nilai rata-rata frekuensi diare antar kelompok kemudian di analisi secara statistik menggunakan uji $\mathrm{T}$, yang akan di ambil berupa perbedaan signifikan dan tidak signifikan. Pengertian perbedaan signifikan ini menunjukan perbedaan yang cukup jauh dari kedua kelompok yang dilakukan pengujian, sedangkan perbedaan tidak signifikan menunjukan hasil yang hampir sama pada kedua kelompok yang dibandingkan, berikut ini hasil dari uji $\mathrm{T}$ yang dilakukan. Nilai uji $\mathrm{T}$ pada penelitian ini sebesar $\mathrm{P}=0,000$ $<0,005$, sehingga dapat disimpulkan bahwa ekstrak etanol buah okra memiliki aktivitas sebagai antidiare.

\section{KESIMPULAN}

Ekstrak etanol buah okra ekstrak etanol dengan dosis 20, 30, dan $40 \mathrm{mg} / \mathrm{kg}$ bb. memiliki efek antidiare yang ditunjukkan dengan nilai $\mathrm{P}=0,000<0,005$

\section{UCAPAN TERIMA KASIH}

Peneliti mengucapkan terimakasih kepada STIKES Mandala Waluya Kendari khususnya Program Studi Farmasi dan LPPM STIKES Mandala Waluya Kendari yang telah memberikan bantuan berupa fasilitas dan dana penelitian sehingga penelitian ini dapat diselesaikan.

\section{DAFTAR PUSTAKA}

Anas, Y., Hidayati, N.D., Kurniasih, A., Dwi, K.L., dan Sanjaya, 2016, Aktivitas Antidiare Ekstrak Etanol Daun Nangka (Artocarpus heterophyllus Lam.) dan Daun Angsana (Pterocarpus indicus Wild.) pada Mencit Jantan Galur Balb/C. Semarang: Fakultas Farmasi Universitas Wahid Hasyim. Halaman 33-41.

Azizi, M.T., 2012, Uji Aktivitas Anti Diare Ekstrak Etanol Daun Salam (Poliyanthi Folium) Pada Mencit (Mus Musculus) yang di Induksi Oleum Ricini, Skripsi, Fakultas Ilmu Kesehatan: Universitas Islam Negeri Alauddin Makassar. Axe, 2011, Antidiabetic and antihyperlipidemic potential of Abelmoschus esculentus L. Moench in Streptozotocin-induced diabetic rat, 
Journal of Pharmacy and BioAllied Sciences.

Fajrin, F.A., 2012, Aktivitas Antidiare Ekstrak Etanol Daun Seledri (Apium graveolens L.) pada Mencit Jantan, Skripsi, Jember: Fakultas Farmasi Universitas Jember, 9 (1): 1-8.

Inayathulla, Shariff W.R., Asif, K., and Mukesh, S., 2010, Evaluation Of Antidiarrhoeal Activity Of Crataeva nurvala Root Bark In Experimental Animals, India: International Journal of Pharmacy and Pharmaceutical Sciences, 2(1): 158-161.

Markham, K.R., 1988, Cara Mengidentifikasi Flavonoid. Bandung: ITB: 1-3.

Misra, A., Srivastava, S., and Srivastava M., 2014, Evaluation of Antidiarrheal Potential of Moringa oleifera (Lam.) leaves. India: Journal of Pharmacognosy and Phytochemistry, 2 (5): 43-46.

Purwaningdyah, G.Y., Widyaningsih, D.T., dan Wijayanti, N., 2015, Efektivitas Ekstrak Biji Pepaya (Carica papaya L.) sebagai Antidiare pada Mencit yang Diinduksi Salmonella typhimurium, Jurnal Pangan dan Agroindustri, Vol. 3. (4): 1283-1293. 